\title{
The Emotional Experience of Crisis Reporters: The Journey
}

Ten-minute vacuum of gaining altitude. In his thoughts, James returned to San Lorenzo for a while. The last news he had got was the growing number of the dead. In one of the pictures, he saw a dreamlike, once civilized but now decaying square. Since the catastrophe had burst out, many hours before the picture was taken, polished surfaces turned dingy, bright paints faded, and healthy plants went black and dusty. There was no life. Everything looked broken, like 30-year-old forgotten scenery from a lowbudget Western film. Never had James seen such a fast downfall. The square was full of petrified-frozen corpses in a line.

Yet, he still knew little about the nature of the catastrophe. Will it resemble a war zone, a natural disaster, an attack? He recalled a very strange week, during which there was a terror attack in Saint Petersburg; Syrian troops launched a chemical attack killing dozens of civilians including children; the US president then "sent a message" to the Assad regime by bombarding a Syrian air base; on the same day, a terrorist hijacked a truck and drove it into a Stockholm department store; on Sunday, the Daesh bombed two Egyptian Coptic churches with, again, tens of victims.

And this happened only in "his world"-Europe, the US, the Middle East. There were also all the thousands who were dying due to draught and much more severe conflicts or bursts of violence in South Sudan, Somalia, Central African Republic, Yemen, Ethiopia, Kenya, Nigeria and DR Congo, Mexico, Myanmar, North Korea. Europeans, including European journalists, had pitifully little information about them. Local 
journalists, who could have raised awareness, lived in a different, far more dangerous world (see e.g. Høiby and Ottosen 2015), and only recently started to be in touch with their privileged Western colleagues (Sven, Farrukh). All in all, the Global South remained an unknown zone.

The catastrophe at San Lorenzo could resemble any of the crises that James was aware of or any of those that he couldn't even imagine.

Thinking of all this, James almost fell asleep. The pressure in his ears woke him up. He, finally, immersed in the thoughts about his colleagues' emotions. What is crisis reporters' emotional experience?

\section{Bored in a News Hole}

A significant part of journalists' professional ideology is based on their onsite presence (Andén-Papadopoulos and Pantti 2013). A prospective excitement and the opportunity "to be there" also lie at the core of the attractiveness of the profession: as a reporter, Ema said about herself and her colleagues at a journalism school, "We'd all wanted to be war correspondents." Anthony explained: "I wanted to see how the planet rolls." Indeed, working as a war correspondent tends to be particularly appealing for journalistic rookies, since it means becoming a part of a myth (Pedelty 1995). Moreover, it's just fun: "it's fun to be in these emotionally powerful situations, there is an adrenalin rush" (Farrukh).

However, face to face with the daily routine work on non-crisis coverage that the journalistic profession largely consists of, the attractiveness may transform into frustration, boredom, and disappointment (as Ema continued: "No one was."). The disappointment is accompanied by disillusionment and disenchantment with the real journalistic practice. This was explicitly stated by Olga during her fight with Marek (both of them in leading positions in one of the $\check{C} T$ newsrooms), when she criticized his submissive way of gaining information:

Marek, but you are a great journalist! [But your practice resembles the] work of an upscale assistant. And I am really fed up with that. I am terribly demotivated. (Field notes)

Indeed, frustration arising from the everyday nothingness, the boredom, and ennui were related to job dissatisfaction or enactment of organizational structure and were particularly on exhibit among Czech 
journalists. Did their post-socialist, less traditionally professionalized, still less independent, more politically manipulated and oligarchic milieu, that was undergoing a problematic "transition" from an authoritarian media system to a liberal system (Örnebring 2009), play a role? Probably yestogether with the concrete organizational settings. The ennui was particularly visible at $\check{C} T$ - a business that was, according to some $\check{C} T$ professionals, less flexible due to its leviathan-like clumsiness, residual practices, and heavy materiality. How symptomatic it was that until recently, the company allegedly had maintained its Department of Typewriters (cf. Czarniawska 2011). One of James' $\check{C} T$ friends even came up with a perfect motto for the company: "Czech Television-you die here" (Field notes). Another colleague, Viktor, agreed:

I'd call $\mathrm{KH}^{1}$ a building of totally burntout people, absolutely, totally. And no wonder. Eeeh. ... The people sink into a terrible routine. I have a terrible problem with that. (Viktor)

According to Viktor, a young reporter, the company would use the beginners' enthusiasm- "suck the people dry" - so that after eight years they would have to leave. They would not be able to bear the health costs of the job.

As a consequence of the disenchantment, some described the everyday atmosphere in the newsroom as "sleepy" (Viktor, Ema), a "standard lethargy" (Matouš), a "dearth" (Richard), or "pure boredom" (Josef).

Surprisingly, the boredom was not limited to domestic and parachute reporters; it also appeared among permanent correspondents and sometimes also among those war correspondents who had reached Ema's dream position and, at first sight, seemed to be ceaselessly interested in "their" territory. For the reason for the lethargy, was "routinization" of the coverage of suffering (Vítek), which arrived even when face to face with turbulent events and the suffering of other people. It was caused by the awareness that "it's not the first time" (Čestmír), "it's not the first trouble of this kind. It's not. Nor is it the last one" (Vítek).

${ }^{1}$ The $\check{C} T$ headquarters. 
The default mental state of most and not only Czech crisis reporters was thus already marked to some extent by compassion fatigue (Moeller 1999): the simultaneous feeling of overstimulation and boredom caused by constant bursts of crisis newsfeed. At the same time, the lethargy could emerge just because the reporters had a gut feeling that there will be another crisis, that no crisis is the last one, that is, that they-compared to the non-privileged reporters, victims, and witnesses who are anything but global citizens - remain relatively safe. Even if they are in the field, even when they do feel endangered, as Europeans, they can withdraw at almost any time: "as journalist, a Western journalist, you are privileged, in most situations you have at least food, hotel, certain security, and you know you will be out of the situations. ... [You tell yourself,] 'but you, my friends, you're gonna sleep on the ground" (Bob). At some point, they would come back home.

This feeling of privilege that- together with the routine involvement in crises - made the boredom possible, also created conditions for guilt feelings - see the section "Moral Dilemmas and Guilt."

The plane's loudspeakers were now transmitting another voice, notifying the passengers of possible refreshments. The voice sounded more human than the metal voice of the robotic flight attendant. It was tired, with imperfect pronunciation and changing rhythms. James could not decide whether the humaneness of the voice was calming or made him nervous.

Indeed, he was nervous. But it was rather the malfunctioning loudspeakers that made him worried. "De-de-de- dear passengers," the loudspeakers stammered, announcing refreshments distribution. Bored and hungry, James felt like ordering panini.

It was not only the boredom of the eternal return of crises. As Nord and Strömbäck (2006: 88) have noticed, nothing happening causes also problems, because the media has a new "hole" which has to be filled. As a consequence, during field work, any "something" — an event or a development that could be considered newsworthy, that is, that was conflicting, negative, surprising/unexpected, of a certain magnitude, and relevant, or in close (cultural) proximity (c.f. Galtung and Ruge 1965; Harcup and O'Neill 2001)—was welcomed as an enlivening break from routine and the most interesting part of the job. As a perfect opportunity to "feed the Hydra" (field notes). These breaks were obvious during the observations: whenever a crisis event happened or developed, people either froze and together silently watched an agenda setter such as CNN on the screens in 
the newsroom (e.g. after 9/11) or started moving and speaking faster (see the example of the killing of Abdelhamid Abaaoud, one of the instigators of the Paris attacks, in the section "Inside-the-Media Is Outside-theMedia Crisis"). The organizations always got a kick out of an event such as the Brussels terrorist attacks:

It's a bit silly to say that, but the newsroom never works better than in such a kind of crisis. (Jacob)

For media organizations, the terrorist attack was an easy piece of news; it just happened and helped to fill in the news hole (McDonald and Lawrence 2004; Nord and Strömbäck 2006). Thus, in Brussels newsrooms after the Brussels attacks, everybody was agile and ready to give a helping hand, so the collective worked perfectly, fast, vigorously. Moreover, the attacks helped to resolve the everyday competition between the digital and paper editions, as they clearly distinguished the respective roles (following the minute-to-minute developments vs. bringing contextual analyses; cf. Reinardy 2011).

Likewise, these breaks were explicitly—and positively—reflected upon by James' colleagues:

Something like that [such as the gun attack in the Paris music club Bataclan] must happen to shake one from that kind of. ... From the cynicism and lethargy. (Matouš)

Any technological unpreparedness of both newsrooms and individual journalists shrinks to vanishing points with time and experience:

The first war, it's terrible. It's like the first love. When you divorce for the fourth time, you know how to go to the lawyer, etc. (Gloria)

Nevertheless, after several days, the non-action developments, for example the continuing state of emergency in Belgium, lost their ability to rouse the journalists from lethargy, as described in the field notes just a few days after the Paris attacks:

Marie says that "we don't look into anything except Brussels, so we are going to work hard today." (...) Marie sits back against the armchair and sighs: "Oh, what a day again. Nothing happens...." (...) After a while, Marie says in a bored way: "I should've brought the knitting with me." (Field notes) 
This ennui was similar to the case of the "migration crisis" with its particular temporality (duration). Since it had started to be tagged as a "crisis" among journalists themselves around March 2015 (as Ema said), it became a constant ongoing event, raising no exceptional emotions. "When hundreds of thousands refugees are coming to Europe three straight months, you just keep it on top until it touches you, even though we all are so fed up with it and tired of it that we don't feel it any more," said Šimon, and returned to his default boredom.

In sum, the journalists James knew often oscillated between boredom and arousal, fatigue, and thrill. "Adrenalin is just like a drug, and you need your shot," said Anthony and draw Russian Mountains with his hand in the air. While the excitement of unpredictable and surprising events (Nord and Strömbäck 2003) disturbs some of the daily emotional routines, Sam Dubberley et al. (2015) point out that the unexpectedness and surprise of the brutality of acts (often in user-generated content) are also those qualities that, according to journalists, trigger the worst emotional shocks.

A strong turbulence. Right in front of James, a flight attendant had to hold onto the cart with sandwiches. James admired the skill with which he, being used to turbulence, avoided falling down.

After ordering his panini, James returned to his thoughts. Never before did he realize that the default emotional style of many of his colleagues was boredom and compassion fatigue (Moeller 1999). Only sometimes, this kind of mood was weakly and temporarily disrupted by an event that triggered distinct emotions.

\section{Emotionally Engaged}

As suggested above, journalists cannot step out of the world. In many respects, they exist in the situations they "cover" as actors. Thus, the reporters James knew could be emotionally engaged in politics. Being aware of the political potential of media, they were becoming indignant over their colleagues' bad journalism or the doubtful ethics performed in other media organizations. Giuseppe, for example, could not stand "the dehumanization of refugees" into a faceless mass and "the brutal lies" about them. The reporters were sometimes passionate about the technological details of the crisis event-like Julian from $L S$, who lost himself in the technological aspects of the nuclear catastrophe at Chernobyl-about the complexity of the crisis, about the truth, and The Truth. Many of the reporters were anxious about sticking to professional standards; for example, Sven talked about the "irrational responsibility not to make errors" he 
felt while reporting on the 2016 Brussels attacks; Tim, writing a news series on a trauma issue, recalled he was "very fearful about the responsibility ... I would have panic attack the night before we would publish the story. ... What if that detail was wrong?" (Tim slept very poorly that year.) Some others were saddened by members of the audience who misinterpreted their accounts (see Sam's quote in the section "Belgium, Czechia, and the Closeness of a Crisis"). Sam was especially angry when in 2013, after he had been involved in an attack in Syria that killed a French fellow journalist, he received hateful reactions:

It made me very angry. Very angry. Very stubborn, but mostly very angry. And very emotional. ... It gave me higher blood pressure. Because of the tension. But mostly because ... afterwards. (Sam)

Indeed, as Marte Høiby and Rune Ottosen (2015: 67) have illustrated, "harassment and threats directed towards journalists in social media, on e-mail, SMS and voicemail is reported to trigger reactions such as insomnia, depression, frustration and anger." The emotions are particularly strong when the criticism is related to the journalists' professional performance, and they also have a greater effect on their ability to work than physical dangers on the spot. Correspondingly, Klas Backholm (2017) lists public debate and criticism related to journalistic work among stressors affecting journalists' well-being.

In short, James' colleagues' emotional engagement was always related, in one way or another, to their strong feelings of professional responsibility, their awareness of the political potential of the media, and their existence within their audiences' community. Thus, many of these emotions were directed toward the journalists' own social space.

By comparison, what follows fully focuses on the journalists' emotional identification with the on-site situation and the on-site tragedies of people. It addresses those emotions that the reporters feel when they are in contact with the crisis as such, its victims and direct witnesses, and mainly those emotions that are most obviously related to the mistaken yet practically existing paradox of reporting and witnessing. The paradox is particularly irrelevant when journalists find themselves in danger or when they bear witness to the pain of others (see Boltanski 1999; Sontag 2003).

Strangely, it was getting dark. Through the window on his right, James saw a distant land. An island of interconnected light spots. It resembled a drawing of the nervous system: nerve fibers, nerve endings, and lots of points. 


\section{Identified}

What and why exactly, then, did the reporters feel once a crisis disrupted the boredom? Sadness, indignation, pity, sorrow, anger, fear, anxiety, panic, stress, tension, empathy, tiredness, compassion, horror, depression, shock, and guilt - these were the most common emotions that one could see and hear when digging into the phrase that covering the Haiti earthquake, the Brussels or Paris attacks, the war on Ukraine, refugee camps, $9 / 11$, the war in Liberia, hurricanes, the aftermath of the Greek debt crisis, famines in Central African countries, and so on was "emotionally demanding” and "affecting” (e.g. Lotte, Nicolas, Sam, Kryštof, Matouš ...; cf. Dubberley et al. 2015; Hight and Smyth 2003; Pedelty 1995).

Most often, the emotions the reporters feel emerge from their identification, and thus empathy — an emotion Antje Glück (2016) considers central to journalistic routines-with the victims and witnesses. In turn, the identification stems from their physical or vicarious presence in the field, with physical presence leading, not surprisingly, to stronger identification.

For example, the reporters very easily identified and empathized with the people on the move, fleeing their countries. Giuseppe recalled an existential moment he experienced while reporting on refugees on their way to Western Europe through Serbia and Hungary:

Once you are in the field, you get involved.... At some point, I experienced that I was not a reporter any more, I was one of them. [After travelling nine hours in the forest,] our aim was not to report on that trip any more, but just to make it. So it was a feeling of fully embodying yourself in the shoes of the refugees.

Giuseppe stressed that he knew he was never in their shoes, but it was the feeling that he had after spending time with them in the forest. Diego went through exactly the same experience, made some friends among refugees, and pointed to how it contrasted with what he had learned at the university. On the spot, not being a part of the story was impossible for him. As mentioned in the section "Belgium, Czechia, and the Closeness of a Crisis," Lilah had one foot in the community of refugees because she spoke Arabic. Similarly, Farrukh said it was important to experience a conflict from within a community, without claiming that the reporter-in his case, the photographer-suffers alongside the unfortunates. 
Although every single one of James' colleagues was different and reacted differently to being in the field, there were diverse streams of emotions typical for one or another crisis situation.

Thus, the identification and empathy felt while covering the refugee crisis would typically turn into sorrow, pity, sadness, compassion, grief, anger, or even depression (e.g. Diego).

Correspondingly, the reporters would feel rage about manifestations of extremism and hatred (see the section "Inside- and Outside-the-Media Crises Resonances").

They would feel despair and revulsion in the aftermaths of natural disasters. Similarly, the aftermaths of armed conflicts, bursts of violence and wars, for example the conflict in Syria, often triggered hopelessness, depression, injustice, and overload:

Sometimes [the Middle East] is a very depressing region to cover, especially the last few years. Sometimes I really feel that for a while I want to do something different. ... Because you really think, uff, this never stops, it never stops! And you really see so much suffering, and you get to know a lot of people. ... And they confront you with their frustration, their anger and hopelessness. ... So sometimes I have this period that I think it's really hard to keep on dealing with it. I just want to shut it out for a minute, just to be able to keep going on. (Lotte)

More precisely, Čestmír talked about the feeling of overload when he saw little hands sticking out of the rubble after the 2004 Haiti catastrophe; Anthony, covering the earthquake in Pakistan in 2005, forever remembered children with amputated extremities and the omnipresent smell of death. Ernest could not stand watching a Catholic church in Rwanda full of Tutsi and Hutu moderates'-men's, women's, and children's-bones and skulls, with blood stains on its walls. Ernest needed to take a break, leave, and breathe.

James took a deep breath as well. What about Rwandan journalists? He knew only about those who took part in fueling the 1994 genocide, claiming at "Radio Machete" and in other "hate media" that the "graves are not yet full" and urging Hutus to "go to work" (The Guardian 2003). Those journalists who lost their lives received far less publicity.

The reporters would feel transfixion, consternation, anger, and fear in terror attacks (Felix, Jacob, Sven, Matouš, Ernest). 
They would be left without any energy, exhausted (Tim, Finn), and would feel a strong sense of responsibility (Judith) while covering individual trauma issues.

Importantly, being on the spot and empathizing with the victims often meant that James' colleagues experienced a sharp contrast between the two worlds - the privileged, "superficial" life in European fashion and food capitals and the crisis zones. In the first, people were troubled by being unable to book a holidays trip; in the second, people were starving and dying. In turn, this existentialist feeling of facing more real humanity during crises strengthened the contact, identification, and empathy with the people affected by a crisis: "I felt more connected to the people I met in the crisis zones-people in big difficulties. Looking at them, you see the real face of a human." (Bob) This feeling leads to developing very deep (albeit often short-term) relationships in the field (Bob, Anthony, Diego, Ines, Giuseppe, Gloria).

But it also means that when you come back, as Anthony expanded on the contrast, few people can understand you. "You get in the shower, you turn on the water, and you're crying, because you have hot water and they don't." (Gloria) In the end, you want to go back. To be sent back, "you are just pretending that you are ok" (Anthony). You cannot show any weakness (see the section "Cynics, Stoics, and Brokens").

Some of the reporters stressed that even mediated crises had the capacity to trigger strong emotions. They argued that given the immediacy, ubiquity, and fidelity of the recording, transmitting, and displaying technologies that the journalists use, the difference between "parachute reporters" (e.g. Cottle 2009) and "armchair journalists" sitting in the comfort of their media organization's headquarters, that is, between immediate and secondary or vicarious emotions, is not that significant any more (Dubberley et al. 2015):

[The relevance of emotions applies] not only [to] people in the field, but also people working in the newsroom. ... You are looking at those screens every day, the whole day. And you know, the horrific scenes that are coming to our screens, it's unimaginable sometimes. ... you don't want to see a beheading. You really don't want to see it, because you will never forget it. ... When there are days and days and days and weeks and months, and it just keeps on coming, even here at your desk, these images after another bomb attack with bodies blown all over the place. It's really horrible to see it. (Lotte) 
Indeed. Although the trip to San Lorenzo was James' first experience with on-the-spot crisis reporting, he had already covered crises from afar. The footage he sometimes needed to watch was nothing nice. Some of his colleagues were able to eat their lunch while watching gory details on their computer screens when they did not make it to eat in the canteen. They could chew their smoked salmon salad while watching people being burned to death in cages. For James this was unthinkable-the cocktail of emotions that this type of footage triggered was too dense.

All in all, the types of emotions the reporters felt varied greatly depending on the nature of the crisis, its duration, its newness, and on whether the reporters witnessed it directly or vicariously.

As the bubble of James' colleagues was rather reflexive and self-critical, some of them condemned the falseness of their fellow media professionals' empathy. As always, the pithiest was Farrukh, who based his disbelief in the media workers' empathy-and his concern about the serious effects such false empathy had for the quality of news - on his knowledge of their work and its political-economic context:

I don't take claims of the emotional disturbance, PTSD, to be serious. Because I don't see people in the industry who are actually concerned, committed to the issue they claim to be covering. ... People are walking over each other and walking over dead bodies to get to the emotionally powerful photograph.

For Farrukh, most people in the industry were ignorant of the situations they were covering and only stooped to politically motivated, lucrative, and self-seeking journalism.

James recalled how enlightening speaking to Farrukh was: his position was unyielding, determined, and defiant. His criticism, often publicly expressed, was well-meant. Friendly fire.

James had to acknowledge that there was something suspicious about empathizing with the victims, yet simultaneously using empathy as a professional resource (Judith) and as a way to protect oneself from guilt feelings (Gloria; see the section "Moral Dilemmas and Guilt").

\section{Parenting}

The narrated identification with the tragedy of the people experiencing the crises was usually the strongest when it came to children. Particularly those reporters who themselves had (small) children often recalled how 
desperate they felt while witnessing the suffering of these little people who were civilian and innocent by definition. The reporters unwillingly identified the children who were suffering, for example, in refugee camps, natural disasters, or civil wars, with their own children. The extraordinary impact of seeing suffering children affected reporters ranging from the openly highly sympathetic (e.g. Lotte, Nicolas, Anthony) to journalists focused on factuality and technological processing of crises (e.g. Tomáš, Jesse, Marie):

I have seen so many stories like this, and so many children, and yeah. I have children of my own, and you just want to give them every. ... All the love of the world, and you want them especially to feel safe and to feel secure. And you know that those children do not feel safe and do not feel secure. ... Yeah, it makes me angry and frustrates me. (Lotte)

I must say, having children by myself, things have become more difficult. If I now see children, I see that I look at that with another point of view than I did ten years ago. Before having children. And I know that working with children or seeing children or reporting on children makes me more vulnerable than 10 years ago. ... The point is that to see children ... because it of course always makes the projection onto your own situation. And what if it would have been my daughter. Well, if you see a dead soldier, you never think, what if it would have been me. Because I am not a soldier. (Jesse)

Children created a link between their personal lives and their professional tasks.

Thus, for Jesse, Čestmír, Richard, and others, having children was also a milestone in their professional career, which further blurred the border between personal and professional identity (Rosen 2011; see also Van Zoonen 1998). Vítek explained the milestone at the end of a long and heated talk:

"The birth of my first child was an absolutely essential moment that formed me as a journalist. Because it, in the best moment, kicked my ass and shot me down from the ... bumptious journalistic cynicism of a young journalistic nitwit. ... It's not about the big picture (shakes his head). ... You must transmit - and it's the emotions-the emotion about what it means that there is no electricity in Aleppo. ... It's about this. About the individual, concrete people. And the fact that my first son was born made me come down to earth and I started to be interested in individual people, and I think 
this makes me a better human. I'm not saying that I am a good person, but it makes me better than I was before (laughs), and when a human is a better human, it certainly makes him a better journalist.” (Vítek)

As Howard Tumber (2011: 328) observed, the idea that emotional identification and responses to disasters-such as that of September $11-$ make better journalists marked changing attitudes toward the norm of reporting (see the section below, "Professional Ideology and Its Critique"); five years later, Glück (2016) proved that journalists attribute a great deal of importance to empathy.

Additionally, having children and a family could also help to maintain hope and fight cynicism: as a parent, "you rediscover the unconditional love. The love for what you are, and not for what you represent" (Anthony). Family (and friends) is the best safety net (Gloria).

Yet, having children is typically complicated for crisis reporters, especially for female reporters. In those countries that James knew something about (see "Creative Nonfiction and the Research Method"), women of a certain age either stopped doing the job because of having children (including some of his colleagues: Olga and Astrid) and never returned to the core of the news service team or stayed, like Lilah and Ines, and never had children. Alternatively, like Gloria, they had feminist partners doing nine-to-five jobs. But having children was hard not only because of logistics but also because, as Anthony suggested, having a "normal family life" is improbable. When you ride the Russian Mountains all the time, you can hardly be understood. Closeness becomes almost impossible.

This was something James was already deeply familiar with. As far as he knew, he did not have any children himself, yet he dared to think he grasped the meaning of the crisis reporters' parental experience. Partly because having children was not the only way by which the crisis came closer.

James took the panini from the flight attendant and started eating it eagerly.

\section{Moral Dilemmas and Guilt}

In less than five seconds, James was completely disgusted; the meal even made him indignant. He continued eating with resignation.

As suggested above, the reporters empathized with victims and witnesses of crises and vice versa: their identification and empathy were essential for having an authentic on-the-spot experience. In this context, Sven 
recalled his impression of Congolese government soldiers who had just come back from the front:

their eyes were really eyes which you don't see in normal situations. I mean, they were like mirrors of what they just saw. They were like open, they were tired, and ... I think then it's also important to identify. If you don't make that kind of identification, you can't really ... if you don't empathize, you can't really be there.

The direct or indirect on-site presence is also at the core of journalists' professional ideology from which they draw their authority (AndénPapadopoulos and Pantti 2013). To Sven, "being there" was impossible without empathizing and identification. But empathizing and identification in turn resulted in moral commitment that did not allow a reporter to witness suffering without taking action:

I am a father. If I see a child that is in [trouble] —and I wouldn't do anything just to keep my story dogmatically clear-I think I would save the child and maybe think about, ok, should I write about it? Or is it too much? I don't want to be the hero of the story. I think I would start thinking in that way. But I think I don't want to be on the side and let the child jump and then write about it. But even more strange would be to not write about it and to say that you actually. ... Eeeh. ... Didn't help someone in danger. I think there is no shame in it. (Sven)

Although, again, it does not make a fundamental difference whether a reporter witnesses other people's suffering on the spot or from a distance, the commitment was the reason why, in the case of the child, Sven could not even imagine continuing to observe and deny his agency. The same commitment was at place in relation to refugees/survivors; the journalists thus ended up giving them a ride (within a country or behind the borders; Tomáš, Josef), lending them a mobile phone (Sven, Tomáš, Matouš), buying them food, water, tent, or sanitary items (Nicolas, Bob, Tomáš), taking care of a little boy who lost his father under the rubble (Nicolas), playing a mother's role for a refugee child for a moment (Lotte), and so on. Indeed, as Luc Boltanski (1999) argues, taking action (albeit in the form of speech) is the only morally acceptable response to witnessing unfortunates' suffering.

At the same time, as journalists, Sven and others are subject to the somewhat inactive journalists' professional ideology (see the section 
"Objections to Objectivity: Emotionality and Professionalism"), organizational codes, and media logic.

The logic of their unavoidable and repeatedly experienced quandary thus looks as follows: Is a journalist allowed to help people in need? Can she commit herself through a speech? And in another way? Is helping the subjects of the story legitimate, in terms of journalists' professional ideology? Is not helping suffering people legitimate, with regard to journalists' humanity?

The reporters' narratives about all the above-mentioned situations revealed that the journalists were very well aware of two types of commitments - that of a Journalist and that of a Human Being, and even explicitly reflected upon the internal conflict of the two roles. Several journalists explicitly stressed the importance of the latter:

The most important thing is to be a decent human being under any circumstances. (Lilah)

I have full respect for the ethical rules of my profession, but I also have full respect for the duties of my condition as a human being. Maybe in five years I will do something other than be a journalist, but I know that in five years I will still be a human being. (Nicolas)

Eventually, some of the reporters therefore did take part in the situations, sometimes even physically; only few of them did not, because they were not sure what to do. Correspondingly, the reporters strongly condemned "vultures" who only use the victims of a crisis, grab a powerful picture, write a heartbreaking story, and vanish without a trace. This went hand in hand with criticizing the use of artificial, inauthentic emotions in news stories (Pantti 2010).

But by helping those who went through serious troubles-being friendly and supportive (Gloria), buying them this or that, or even supporting some of them on a monthly basis (Bob) - the reporters also reduced their sense of guilt of being privileged, being fine, being able to get out of a dangerous situation:

How can you just say goodbye and then not feel guilty about being rich? I am guilty about being rich, we should be, in this part of the world. (Bob, sitting in a library in Copenhagen)

You feel bad because of not crying. (Diego) 
I felt guilty when we left in the evening. ... I was in trouble with them as long as I wanted to. But they had no chance to get out of it. (Giuseppe)

Bob, Gloria, Diego, and Giuseppe felt that by helping in one way or another, they were sharing the benefits they derived from the stories and images they obtained in the field. Obviating guilt feelings was also important for their mental well-being (see the section "Coping Strategies"), as guilt feelings and moral dilemmas are among important stressors (Backholm 2017).

Sometimes a dilemma and a guilt feeling stayed in a journalist's mind and heart for years, though. Indeed, as Hopper and Huxford (2015) point out, journalists can be deeply troubled by once-acute emotions that they merely deferred/postponed but did not completely suppress, even though the events that triggered the emotions happened years or decades previously. James recalled a memory Nicolas told him about, many years after he had experienced it. For James, this was one of the most emotionally powerful stories he had ever heard from his colleagues:

I always saw it as a moral image, not a stressful image. It's a rape. (Pause) Ehmmm, a scene of gang rape in Africa. (Pause) I just arrived. ... The problem is not the rape itself. No. The problem is ... So this is very egoistic as a reaction-I arrive in a car, the village is burning, and I see that two gunmen are taking a woman from a hut, the hut is burning, and they start the rape. They have assault rifles, I am a journalist, I have no rifle, I am just arriving at the scene with my car (pause), the driver stops, because he feels there is something to be done, and I tap on his shoulder (makes knocking sound), I say, go. We leave. We cannot, we cannot do anything. We don't have a weapon, the wife. ... I don't know what will happen, or I can know, I can guess what will happen with the woman, we are in a war zone, the village is burning, they have weapons, and as a man you have to say, ok, I just flee. And after that, you just have to live with what you did. I was just thinking today it was a good solution. But that's something awful. Because I was not prepared to do that. I was not prepared. In all morality, you say, hey, I would get out of the car and ... Be shot. And be shot. That's it—be shot. So I just think about that, I think that I had no. ... When I came into that, I would say drama, I had no guideline coming from my boss, coming from another journalist, or from my environment. I just made mentally the calculation, saying, I should, but I can't. Get away. (Pause.) And after that, you just think ... (Pause.) So I know it's something I wrote, and it helped me to write it in order to confront what I did with public opinion. I wanted to know if one reader would say to me, hey, Mr. Bernard, you did a war crime. I don't know what. No? 
Nicolas' apologetic way of telling about the situation-posing rhetorical questions, simulating a dialogue, arguing without any outer prompting - shows that the sense of guilt from reacting in an egoist way, as he said, stayed alive. Similarly, Julian from $L S$ talked about a policeman who long ago committed suicide for reasons related to Julian's investigative reporting: "He committed suicide. Am I responsible? I don't think so."

Nicolas, Julian, and others made sense of the moral dilemmas and their solutions by retrospective justification of their action (Weick 1995). Such sensemaking was not built only on a mix of immediate calculation and instinct for self-preservation but clearly had an organizational dimension: namely commitment to and enactment of professional principles (ibid.). The journalists first of all had to stay alive and do their job. This kind of sensemaking helped them to reduce the (potential) strain following from both cognitive and emotive dissonance (Festinger 1957; Hochschild 1983): a discrepancy between thinking and/or feeling, and action. Nicolas, for example, drew the three closer together by rationalizing his spontaneous action and placing it into the media-organizational context (boss, other journalists, environment, articles, and readers). The media organizations thus worked as both poison and remedy: they were bringing forth moral dilemmas and guilt but also providing, sometimes insufficient, justifications of solutions. The reporters' personal and biographical sensemaking narratives often had this smoothing effect; never did a journalist come off badly, never did she play the part of an immoral, inhumane, or unprofessional character. On the contrary, she often fitted into the selfmyth consisting of morality, adventure, and bravery (see Pedelty 1995).

However, the existence of moral dilemmas, guilt feelings, and the need to make sense of them through a personal narrative also illustrates well the above-mentioned individualization and biographization of risks and crises. Moral dilemmas and guilt feelings, emerging from a crisis and newswork (i.e. social phenomena), and perhaps also from a Western collective sense of "guilt of being rich" (Bob) at the expense of non-white peoples (Farrukh), can easily be shifted as a burden of risk onto the shoulders of individuals. Then, the guilt feelings turn into anxieties and neuroses (Beck and Beck-Gernsheim 2001; Scheper-Hughes and Lock 1987).

Behind the dilemmas and the help that the reporters provided to the unfortunates, there often was an attempt to reduce, albeit imperceptibly, the gap between the contrasting worlds, and a kind of vague, dispersed, everyday struggle for democratic principles of human co-existence, solidarity against populism, xenophobia, and inhumane living conditions. For 
example, Lotte's attempts to contribute to improving refugees' conditions by reporting on refugee camps worked as a strong professional motivation:

And I really want to find energy to keep going, because you hope that you make a difference by sharing their story. (Lotte)

However, such open acceptance and performance of the journalists' active role in public discourse and perhaps also the social milieu was sometimes harshly criticized by colleagues, rivals, and superiors. Marta, an experienced foreign correspondent, was criticized for her "activism" by all these groups. For example, Vítek, a foreign correspondent from another media organization, said she had long ago ceased to be a journalist and became an activist; apparently, the two identities were irreconcilable in his view. Marta's superior also used the label "activism" for any reporters' practices that, in his view, resulted in distorted, "overly positive" news. Later, Marta left her very stable and comfortable position for a relatively uncertain and demanding job in an emerging progressive paper where she had more freedom. This kind of criticism lays bare the double humane and journalistic commitment that James' colleagues faced. Not only Marta's boss but also other editors-in-chief had problems with "activism," that is committed speech acts performed face to face with others' suffering.

The extent of openness about one's involvement often corresponded to the reporters' view of the place of reporters' emotions in their reports and news (see the section “No Torn Children's Life Jackets': Good Taste, the Organization, and Morality"). Tomás, for example, said he did not want to admit or include his act of buying food for refugee families in his report because he found it irrelevant and too openly partisan. On the contrary, Sven, who lent his mobile phone to a Syrian man who needed to call his family, then decided to admit it:

I thought, oh, this is really strange for a journalist. Now you are participating in the story. And then I said, well, I'll just write it, and then the readers will know that I'm in the middle of it. (Sven)

Obviously, many of these decisions and attempted resolution of doubts about involvement/detachment, activity/passivity, and overtness/withholding were preceded by thorough reflections. These reflections on, and solutions of, the moral dilemmas and potential guilt feelings then directly reflected themselves in the journalists' work, mainly in the particular 
objectivity-as-a-practice (Carpentier and Trioen 2010) that the media professionals performed (see especially "Technologies of Sign Systems: Output Emotions").

James glanced at the top of Sophie's aesthetically appealing hair-do: what would she have done in Nicolas', Sven's, Tomáš's, Giuseppe's situation? Her gender must make a difference in these types of moments. James imagined her moral dilemma while witnessing a gang rape would have looked differently. She might also feel a different type of fear.

For a moment, he wanted to ask her. Then he swallowed the question. Not only was he nervous with women but he also realized how awkward and inappropriate asking a stranger about her feelings could be: "Hey, Sophie, aren't you afraid of your sources?"

\section{Danger and Fear}

Here, it can be that you receive a blow from a cobblestone, but it means that you were standing in the way. There [in Ukraine or areas controlled by Daesh], you peek out and get a bullet blasted through your head. (Josef)

Danger and risk appear to be intrinsic conditions of conflict reporting. Media scholars increasingly speak about danger that journalists expose themselves to in the context of wider media professionals' precarity. For example, Silvio Waisbord (2019) sees the economic transformations, the precarization of journalists' labor, the rise of anti-democratic forces, and anti-press violence as the major vulnerabilities of contemporary journalism. More specifically, Mark Deuze and Tamara Witschge (2018) articulate how the networked character of newswork has become a common denominator of several aspects of the transformation of journalism, including the outsourcing of risks: the increasing reliance of new organizations from the Global North on local contacts or freelancers, with the tariffs for freelancers declining at the same time. Tim Rosenkranz (2019) then links this externalization of risks of crisis news production onto the freelancer to lean capitalism and the phenomenon of speculation.

James used to hear terrifying stories, some of which went public and turned their characters into heroes (and corroborated the myth of the war correspondent; Pedelty 1995). Abductions, assaults, bombings, intimidation, and being followed by a hired killer were only the most dramatic of the dangerous experiences that James' colleagues (at least Mario, Sam, Carl, Čestmír, Josef, Vítek, Nicolas, Anthony, Giuseppe, and Tomáš) sur- 
vived-but not always their fellow reporters or photographers. The emotional counterpart of the dangers was fear:

I feel the fear. Each time that I go [to the Middle East], actually. There are certain points, certain moments, when I feel it. Especially before arriving. The days before arrival, the hours before arrival. ... And I don't like ... because I go to Turkey, then to Iraq and then to the frontline, I feel ... I especially feel the fear of the unknown. (Sam)

The danger, fear, and the self-preservation instincts and strategieswhich, according to experienced conflict reporters such as Čestmír, Sam, Josef, and Vítek, could be gained through social learning processes and specialized education (such as hostile environment trainings for reporters)-have significant consequences for the news.

First, media organizations, prudently enough, have recognized some parts of Syria, ${ }^{2}$ Iraq, North Korea, and so on, as "uncoverable" (Josef). However, this might not apply to freelancers, a group of journalists facing increased precarity (Creech 2018; Hesmondhalgh and Baker 2011), who at times go to uncoverable areas and into dangerous situations to succeed amidst competing media professionals and organizations, often without being able to afford, among other things, a fixer or insurance. Spanish journalists in particular told James that they either directly faced this heightened form of precarity and/or perceived it as a pressing problem. In Spain, a country with the second highest unemployment rate in the European Union (15.2 percent in summer 2018; Statista 2019), young reporters like Diego and Ines had little choice and often had to start as freelancers. Later, if they did well, they might obtain a regular salaried job (if they wanted to). However, they were often trapped in a vicious circle, because doing well while facing the dangers of a freelancer was more difficult than working their way up in a media company:

because to cover news in a conflict is very expensive, insurance and everything. And when I was a freelancer, I couldn't ... I have to say I didn't cover things in a proper way, sometimes. Because ... for example, I didn't have the vest. Or I didn't have the helmet. ... But I did it, which is not the best way to do it. (Ines)

\footnotetext{
${ }^{2}$ Syria is currently the most dangerous place for journalists and the level of violence directed to them is unparalleled, because, among other things, some parties of the conflict do not need journalists at all (Creech 2018).
} 
Therefore, Gloria, who herself had a stable job for many years in one of the established Spanish media organizations, passionately argued that

Media must pay and must insure these people even when they are freelancers. Freelancer does not mean a Kamikaze. And now they are like Kamikaze, because nobody takes care of them. ... if they send them to the war or they accept the reporting from the war, they also must accept the obligation to protect them. (Gloria)

Protecting freelancers as well as employees could be a way to redistribute the risk and equalize the higher precarity of the former.

Yet, "the gravest threats are often felt by the reporters, photographers, bloggers, and fixers who call sites of conflict home" (Creech 2018: 576): for example, almost 90 percent of journalists who have been killed in Iraq were Iraqis, and almost all journalists covering Mexican drug cartels were Mexican. Western media researchers, busy conceptualizing the perceived crisis of contemporary (Western) journalism, tend to ignore the safety and other problems faced by local journalists (Hanitzsch 2019). Solving the problem of the most severe threats of violence faced by local journalists and fixers, who perform labor that is invisible to Western audiences, is far more complicated and at present involves mainly NGOs and foundation bodies (e.g. the Committee to Protect Journalists and Reporters Without Borders) that have advocated more comprehensive safety policies than media organizations (Creech 2018).

Second, as Ines and Čestmír suggested, it seems that sometimes the fear is inversely proportional to the quality of reporting:

It's a permanent, permanent struggle of yes and no. Where you put the camera, and where you don't. If you go a metre further, or not. And this is the border that decides whether you come back, or you don't come back, and at the same time the border is often about whether the report will be even better, or not. (Čestmír)

Again, this has a lot to do with media competition and the transformation of newsrooms into "networks of loosely affiliated competitorcolleagues" (Deuze and Witschge 2018: 176), so that freelancers might be more willing (or pushed) to go the fatal meter further and fit into the newswork environment which "demands journalists today to be committed well beyond what any profession could ask for-without most of the 
securities, comforts, and benefits enjoyed by being a member of a profession" (ibid.). Needless to say, the endangerment tended to be physical and psychological at the same time.

Some reporters who frequently found themselves in dangerous situations dismissed their own position and focused rather on their subjects' and talking heads' danger and fear or even on the danger for equipment. On one hand, this stance logically followed from the comparison of the reporters' luxury (Lotte, Anthony) and privilege (Jesse, Bob, Farrukh, Giuseppe) and the misery of the unlucky subjects of the news: "I would make a distinction between what you have to feel as a journalist and what the victim you interview feels. It's far more important. ... How would you dare to think about your own trauma?" Nicolas once asked James.

On the other hand, journalists who refused to adapt their behavior to the dangerous circumstances and their fears were sometimes condemned by others as "adrenalin junkies": "the people who are so obsessed by the profession that they are able to risk their life for it" (Matouš). The reprehensible aspect of such conduct was that adrenalin junkies give precedence to their psychological needs over professional values: "if he searches for an adrenalin rush, he searches for excitement, not the truth" (Vítek). Correspondingly, Anthony listed such "feeding of one's ego and being in the centre of interest" among bad reasons to be a crisis reporter. By some, adrenalin junkies were perceived as similar to the vultures: feeding off of others' suffering, selling a powerful story, and moving on to the next in a heartbeat.

Yet "adrenalin" was a very ambiguous expression. First, those who were considered adrenalin junkies by their colleagues often spoke of other reporters using the same words. Second, even exceptionally thoughtful journalists such as Anthony or Farrukh admitted that adrenalin matters. Third, in the Czech context, the label of a risk and danger fetishist even resembled a challenge trophy (cf. Pedelty 1995) and was handed down from generation to generation. Jukes' findings about reporters involved in crisis reporting suggest that affective detachment has the same status in Anglo-American journalism: his interviewees wore and cultivated their detachment as a badge of honor having the magic property to validate journalism both to themselves and to the outside world (Jukes 2017). In a few cases, losing the image went hand in hand with parenthood (see the section "Parenting"). 


\section{Waging Diffused Wars}

Occasionally, the extent of identification and actorship reached a level at which the reporters were involuntarily waging diffused or hybrid wars (e.g. Hoskins and O'Loughlin 2010; Mejias and Vokuev 2017)—wars embedded in the media and produced by media-and they were aware of it, which intensified their sense of endangerment.

This started after September 11 and applied, for example, to the "war on terror": Josef, for instance, thought that "The ISIS is the first conflict in which the target is really journalists. Systematically." Lilah thought the same. Bob and Anthony believed that it was the case rather for American journalists, perhaps Brits, and that continental Europeans were still relatively safe. Be that as it may, since terrorism profits from media exposure, media professionals' quandary - the paradox of their involvement and detachment - is made more difficult by their active position and involuntarily political capital within the emergency state: either they lend terrorists legitimacy and credibility or they overly rely upon the interpretation framework offered by the public and military officials and experts (Falkheimer and Olsson 2015; cf. Hallin 1986). Being aware of this quandary, many of James' colleagues, and even whole departments, newsrooms, and media organizations, explicitly reflected upon and elaborated policies for reporting on Daesh and its European activities:

Because we work here and have to weigh words. ... When you say 'terrorists executed a man'-execution is a legal act, right. ... so you basically put it at the level of ... the state, which has a monopoly on violence, on the use of violence. ... But it's not, it's a murder. It's a totally ordinary murder, what they were doing. So this is one of the things that is terribly sensitive. And, of course, we try, now mainly in relation to Islamic terrorism, we do our best to plan and not to play. ... Not to play the role and not to be simply a speaker of what they want. To spread the terror, spread the paralysis from whatever madness they've done again. So very ... We have set completely clear rules about what to show and what not to show. We don't show any moving images of the videos that they release. The person who is supposed to die, the victim, is always pixelated there, because it's ... It's precisely in accordance with the code, we don't show victims of crime acts-this is a crime act, it's a murder. ... We won't show him as the dehumanized object of the propaganda of ISIS. (Čestmír)

In his long explanation, Čestmír revealed a lot about how the involuntary role of the press within an information war becomes embedded in and 
reflected by organizational strategies: codes, rules on using footage and words, and so on. Indeed, words are a crucial weapon-Sven and Sam also stressed the power of "loaded words" that have the ability to "indoctrinate." The "war on terror" was thus an obvious example of journalists' active role in crises, which raised questions about the possibility of detachment, neutrality, and emotional disengagement.

However, the journalists became similarly (emotionally) embroiled in other conflicts-mainly the Russian occupation of Crimea and the "hybrid" war in eastern Ukraine (Mejias and Vokuev 2017; see also Rutten et al. 2013):

Regarding Russia and Ukraine, it's ... The number of [hateful] e-mails that you receive for each single report, it's simply unbelievable. (Ema)

James' Czech colleagues were also worried about the attempts of fake news outlets to discredit their work. James recalled a Pulitzer Prizewinning series of New York Times reports (Russia's Dark Arts 2016) on Russia's covert projection of power that he had read some time ago. In East Europe, the Russia's influence was an issue even before Donald Trump was elected, who knows with whose help, the US president.

To summarize, crises had the potential to disturb the newsroom/onthe-spot boredom and could result in closeness, identification, empathyin particular when children and parenting were at play-and in strong emotional involvement (see Zelizer and Allan 2011). The possibility to stay emotionally detached further diminished with the moral quandaries and guilt feelings that the reporters often faced, danger they experienced, and diffused wars they involuntarily waged. At the same time, the corresponding emotional distress - the moral dilemmas, feelings of guilt, fear, and sense of responsibility-reflected itself in the media content.

The robotic flight attendant still looked pretty bored, though. Her neutral yet terrifying face and body-even more terrifying now, in its increasing tiredness - emerged from the nose, pushing a similarly angular waste cart. James collected all his waste and threw it into the precisely shaped cart.

\section{Cynics, Stoics, And Brokens}

"What is your research about?" asks Čestmír when I enter his office at $\check{C} T$. "I'm interested in the specifics of crisis reporting," I reply. "You'll soon find out that we're a bunch of cynical psychos." (Field notes) 
Thinking through the emotions on the output, James became aware that the reporters' emotions were carefully managed (see Hochschild 1983; Illouz 2007). As such, they fit into the realm of sociology and anthropology, rather than psychology. Being biologically preconditioned, but to a large extent culturally determined, defined and shaped practices of feeling and thinking, emotions are not substances to be discovered; rather, they are ways of practical engagement with social context, structured by our forms of understanding the context's cultural and historical specifics (Flam and Kleres 2015; Rosaldo 1984; Scheer 2012; ScheperHughes and Lock 1987). This does not mean that sociology and anthropology withdraw the body from the concept of emotions: quite the opposite. The body as a plastic, time-bound, socially situated, and adaptive phenomenon absorbs and is shaped by the wider political and social conditions of its existence (Scheer 2012; Scheper-Hughes and Lock 1987). This is how emotional cultures or styles (Illouz 2007), that is, ways of experiencing and performing emotions typical for certain groups of people and/ or periods, emerge. ${ }^{3}$

Perhaps most importantly, what makes reporters' emotions a sociological problem is the very practice of their individualization and biographization (Beck and Beck-Gernsheim 2001) by the actors themselves: the practice of appropriating and taking responsibility for handling (or blaming oneself for not being to handle) certain emotions-often negative emotions, such as anxiety, guilt, and fear. While these emotions stem from the crisis reporters' professional context including crisis situations and newswork, they are shifted as a burden of risk onto the shoulders of individuals. Thus, the sociological problem, further addressed in the chapter "Touching Down," resides in the process of internalizing this professionally and contextually determined emotional culture and making it personal and private.

The existence of such emotional craftsmanship and the idea that emotions provide an important missing link between body, mind, individual, society, and politics also means that individual emotional response is structured by our forms of understanding. Emotions entail not only feel-

\footnotetext{
${ }^{3}$ Eva Illouz calls the capacity to display an emotional style "emotional competence." Each emotional style is defined by a specific emotional field: "a sphere of social life in which the state, academia, different segments of cultural industries, groups of professionals accredited by the state and university and the large market of medications and popular culture intersected to create a domain of action and discourse with its own rules, objects, and boundaries" (Illouz 2007: 62-63).
} 
ings but also thoughts and cognitive orientations, our sense of cultural ideology, and public morality (Rosaldo 1984; Scheper-Hughes and Lock 1987). As Michelle Rosaldo (1984: 143) puts it, "Emotions are thoughts somehow 'felt' in flushes, pulses, 'movements' of our livers, minds, hearts, stomachs, skin. They are embodied thoughts, thoughts seeped with the apprehension that 'I am involved." Understanding emotions as practices including not only the self and other people but also language, material artifacts, and environment, practices involved in stories that we both enact and tell (Rosaldo 1984; Scheer 2012), allows us to bridge both the imaginary gaps between cognition and feeling and the discourse and action.

The food had been eaten, the waste had been thrown away. Nothing remained. The flight advanced to its second half. There was no obstacle between James' present bodily state and the catastrophe at San Lorenzo. He started to feel its imminence.

Following James colleagues' emotional paths, diverse strategies of dealing with emotions such as empathy, revulsion, consternation, sadness, fear, or guilt emerged, and the strategies' varied results.

\section{Emotion Postponed and Accumulated}

Typically, the journalists recalled that their emotional reaction to a crisis situation was inhibited and postponed until they came back/home from the site/the newsroom (from a refugee camp, from the Balkan route, from a screen with graphic consequences of terror). While being on location/at work, they felt less sorrow, pity, sympathy, and even less anxiety and fear than afterwards:

On the concrete spot it's of course charged, a lot, it's emotionally demanding, because, of course, you're in the middle of mud with thousands of people and with children, see, and at the same time you realize that the people keep going and going and going. ... (...) Nevertheless, at that very place it did not affect me as much as when I was not there anymore. (Kryštof, speaking about a refugee camp in Hungary)

The journalists often postponed the emotions because they simply did not have enough time to be moved:

9/11 for example, I didn't realize what I was seeing. And what was happening. It was just on automatic pilot. You know? Very business-like. 
These are the facts. So many dead. And th-th-th. And th-th-th-. ... I shut out all emotion. ... And it was only afterwards that I realized [what happened]. (Lotte)

Similarly, Jukes talks about "putting himself on autopilot" as about a specific emotional style residing in distracting himself by working 18-hour days (Jukes 2017: 265; cf. Hochschild's term "going into robot" /Hochschild 1983/ mentioned in the section "Technologies of the Self"). Indeed, the task, the demanding mission, often overshadowed any possible authentic emotional experience of crisis:

It's very difficult to speak about emotion in a ... In a crisis moment. I would say. Because everyone is so focused on what is happening. (Louis)

You don't deal with it until you finish the report. (Ines)

As a result, the journalists often simply did not feel any emotion that they would need to put into cold storage, they acted not superficially but deeply, as Hochschild (1983) calls the practice of tricking even one's self into believing that there are no emotions to be felt.

This way of handling one's bodily emotions, their suppressing and postponing "for the sake of an ideologically driven, detached professional self" (Hopper and Huxford 2015: 38), became habitual:

Occasionally during the rush, when one realizes what has happened, the emotion comes back. But at the same time, it's a kind of ... state. In particular, in the foreign news, one works with these kinds of events on everyday basis. And there is a distance, maybe a defence mechanism. (Matouš, speaking about the Paris attacks)

Buchanan and Keats (2011) echo Matouš's view of the defensive effect of distancing oneself from a crisis by listing the self-control of the reporters' emotions among their coping strategies.

The level of predictability and newness (Nord and Strömbäck 2003) does not seem to make a difference when it comes to the habitualization of the emotional experience. The journalists James encountered were equally able to emotionally adapt to the tragic "state" of the "migration crisis" and to the subsequent developments of terrorist attacks (see the section "Bored in a News Hole"). At the same time, those who considered themselves less experienced could be strongly shaken by the sudden strike 
of the Paris attacks as well as by a working trip lasting a few days in Hungary or at the Greek-Macedonian border.

At that moment, James himself was strongly shaken: another intense turbulence occurred.

It took hardly four seconds, but the unpleasant surprise caused Sophie, who had just gotten to her feet, to stagger and catch hold of James' headrest.

"Another fall?" Sophie gave a laugh.

"Would be nice to have a point event before touchdown," James jested.

Sophie guessed right that he was a journalist too. "Two birds with one stone!" she replied.

Both laughed. The exchange, although rather predictable and not really hilarious, put them at ease. For James, this humor was a bit too much gallows, though.

He would never have confessed it, but the ease had a subtly hysterical aftertaste.

The flight was progressing, and James felt bodily unrest. He could not find a comfortable position. Every stimulus that would be hardly noticeable under ordinary circumstances felt suddenly unbearable. James took his shoe off and spilled a little stone out of it.

Although the reporters were able to postpone and shut out an immediate emotional response, crisis events were not without cumulative, stealthy consequences. As Nicolas precisely said,

Every shock, every emotional shock you get, is not something you can get through with no problem. It is something that will.... It's a little stone that you will have in your luggage. And all the stones are accumulating. So it is not true to say that everything that does not kill you makes you stronger. That's not true. Everything that you have, in terms of emotional stress, is something that makes you weaker and weaker. So you have to deal with that. At some point, you have to make clear, ok, you are just a human, you take things, and you have to get some distance from it. Ignoring it is not enough. You have to deal with it. (Nicolas)

Anthony agreed: it would have been much better for him to (try to) express what he felt each time he came back from a conflict zone. If he had done it, perhaps he wouldn't have nightmares now, he wouldn't smell the death that he still smells, he wouldn't hear the noises, he wouldn't continue to see the faces of the victims. 
The way of dealing with emotional shocks-or not-followed three ideal-typical paths, corresponding to three ideal-typical emotional styles (Illouz 2007). ${ }^{4}$

\section{Brokens}

James did not meet any journalists who were noticeably broken at that moment.

At least not at first sight. At second glance, as he traveled down the rabbit hole, he started to meet empty bottles, squeezed out blister packs and traces of other panaceas. Seldom, panic-stricken eyes flickered from the darkness, but immediately vanished, startled by other observing eyes.

A few times had James had the chance to meet someone Broken in person. Several reporters told him that they had had problems with alcohol or that they had been seeing a psychiatrist (which, after all, could show also strength). Often, he used to hear pitiful or condescending stories about the pasts of some of his colleagues and mainly his colleagues' colleagues, sometimes told by those in leading (Marek, Čestmír, Olga, Marie) or informally supervisory (Bob, Nicolas, Jesse, Vítek) positions:

And we have people that are just on medical treatment, that are ill. (Nicolas)

A half of journalists are alcoholics. ... I don't have a survey on how many journalists work only based on anti-depressants. Hard to say. (Marek)

As Hopper and Huxford (2015, p. 37) observed, "there was a lot of truth 'in the old stereotype of the reporter who heads straight to the bar at the end of the day." 'According to some, alcohol had a prominent position among the cure-all treatments, for it had therapeutic properties (see the section "Coping Strategies"). Some of his friends were so thorough in undergoing therapy that during their talks, James sometimes had a hard time keeping up with them.

James stopped the flight attendant, who was just passing by, and ordered a beer.

${ }^{4}$ This is to say that there were almost no "pure" Cynics, Stoics, or Brokens. Rather, according to the journalists' narratives, these were positions and roles that they entered and exited in different life periods and professional moments. At the same time, not every journalist had tried all the emotional styles. 
Cynics and Kynics: Pissing Against the Idealist Wind

Luckily, probably most of James' colleagues were rather Cynics, the typical postmodern characters (Bewes 1997). More precisely, according to their own narratives about their emotional paths, suspending the emotional reaction and distancing oneself from the emotionally disturbing experience of witnessing close or distant suffering, as seen from a long-range perspective, led to cynicism:

My father told me, 'haven't you become hard-bitten?' (...) You really get hard-bitten. (.... ... if I broke down every time, I couldn't do it. (Ester)

I think that one displaces the emotions somewhere, and it must seem to you that we are a bunch of ironic fellows. But I think that without such an attribute one couldn't work here. (...) ... it is terribly cynical, but that's the way it is. I think that people gain experience and get tough. (Marie)

Cynicism, however, was a cause for concern:

It is dangerous, see, because when you are living in it, you realize that the only rescue is cynicism. But cynicism means suppressing your own emotions, I'd say. And it's putting your ass on the line a bit, then. (Kryštof)

Anthony said that as a crisis reporter, one loses naivety with time. Principles, like justice, vanish face to face with the reality. When this happens, one must fight not to become cynical, because, "When it does not affect you, then you are a limited human being, you're not a good psychologist and probably not a very good journalist." (Bob) For Bob, like for Lilah, the moment of becoming cynical would be a sign of their need for a break. In short, becoming cynical, while being often the only way how to manage crises, threatens both good journalism (cf. Glück 2016) and the individuals' mental health.

Norbert Elias would agree: "only the insane can remain totally unmoved by what goes on around them" (Elias 1956: 226). Foreign correspondents interviewed by Mark Pedelty expressed similar worries about the long-term effects of sublimating emotions: "It has killed me, something in my mind," his interviewee Alonzo said, "We don't have any more feelings" (Pedelty 1995: 199-201).

Some of James' colleagues' criticism of cynicism as such, and of their cynical fellow journalists, was for the same reasons that they condemned 
the "vultures" (see "Moral Dilemmas and Guilt") and the "adrenalin junkies": the cynics "who are not affected by anything" (Bob), who feel responsibility neither to their sources nor to their readers, and who exploit dead and injured black bodies (Farrukh), are considered the bad guys of crisis reporting or crisis photography. However, while the vultures practice bad journalism for success, the adrenalin junkies do it for their ego, and the cynics are almost inevitable products of their working conditions.

Pedelty (ibid.) concludes that "Emotion, if not humanity itself, is the first element to be filtered out in the disciplinary process." Obviously, the crisis situation and the machine of newsmaking not only condition the emotional experience; crisis reporting also requires a certain emotional posture, finding the right balance of disengagement, nonchalance, and interest that Chris Peters calls "American Cool" (Peters 2011). Somewhat more dramatically, Mark Pedelty writes that

this type of reporter, the war correspondent, is like the accountant who rides a Harley. He projects a renegade identity to himself and the world in a desperate attempt to live up to the American myth of the independent man. (Pedelty 1995: 24)

The use of "he" is not random in Pedelty's account. Male reporters in particular tend to be subject to the machismo in the myth. Carl said that "The macho culture formed me a bit" and explained how it helps in his profession:

I have seen people being shot in front of my eyes. ... A lot of young reporters are trained in an academic way, so they have a lot of knowledge and know a lot of technical stuff, but it's the human aspect which makes it more difficult. ... [They have] more problems than people who are used to it.

James thought of how to escape from the cynical trap. In the very near future, he will most probably need to suppress his emotions to be able to work. Yet if he overdoes it and appears cynical, he will be condemned for bad journalism.

It is essential to distinguish two forms of cynicism here. The first one follows some of the principles of classical, ancient, intellectual cynicism, or kynicism (Bewes 1997; Navia 1996). Kynicism, an infallible strategy of shutting the emotions out, had a prominent position among all defense mechanisms (see the section "Coping Strategies"). It took the form of 
critical irony, mockery, satire, sarcastic remarks (cf. Fleming and Spicer 2003). Kynics were joking about mass casualties, suffering, or dangerous developments of international politics.

I use it during terrorist attacks. You might have heard it: the word 'bits' for the number of dead. ... One would go nuts, so I somewhat cynically say, look, fifty bits there. (Tobiáš)

James took part in one of the most brutal cases of this "pissing against the idealist wind" (Sloterdijk 1987: 103) at $\check{C} T$ :

Smoking. The head of broadcasting announces he cannot reach Vítek [one of the foreign correspondents, his colleague]. Vítek wrote to him from his Czech number some time ago, but not lately. The others-Matouš and Ema-are joking: "he's drinking in Prague and we think he's in Turkey!" ... Matouš asks again: "What about Vítek? Maybe he died! If he died, we'll make a special for him," Matouš laughs. I say that if he's in Prague, then he hasn't died. Ema says that a man, who, while on holiday, goes to do some shooting at a military camp, cannot die. ... We are laughing. The whole thing is conceived as a joke. Matouš asks whether any $\breve{C} T$ reporter has died. On our way back, Matouš says that Vítek really disappeared. (Field notes)

In the end, Vítek, luckily, did not disappear. But behind every joke there is a grain of truth. For some days, James could not get rid of the idea that if Vitek had died, his colleagues would have been eager to prepare a special broadcast. They would have been able to work even on this issue and under these circumstances (see Sloterdijk 1987).

Essential for this classical cynicism, or kynicism, is truth-telling and care of oneself (Foucault 2005), and especially intellectual rebellion against many existing beliefs and practices, manifesting itself via satire, irony, mockery, and so on.

The second form of cynicism is inverted and contradictory: modern cynicism (Sloterdijk 1987). Modern cynicism is an ideology and a social phenomenon in which human aspiration is lacking (Navia 1996; Sloterdijk 1987). The modern cynic is apathetic, refuses to engage with the world (however antagonistic her position toward it can be), is resigned to her experience of alienation, and rather flees into solitude (Bewes 1997). Therefore, it fails to meet the moral commitment to take action when witnessing others' suffering (Boltanski 1999). 
The posture of neglecting the emotionally demanding character of tragic events corresponds to Peter Sloterdijk's definition of the second form of cynicism as an ideology in which "the ability of its bearers to work - in spite of anything that might happen, and especially, after anything that might happen" (Sloterdijk 1987: 5) is central. At the same time, however, the cynical emotional posture is precisely one in which kynicismirony, mockery, sarcastic remarks-has its place. As such, the cynical ideology does not only contradict kynicism. It also acknowledges and absorbs the kynical critique but insists on maintaining the existing state of affairs. The cynical ideology, which Sloterdijk calls "enlightened false consciousness" (Sloterdijk 1987: 5), is thus resistant to any critique, for it recognizes the particular ideological interests and the distance between the ideological mask and the reality, but it still finds it reasonable to retain the mask. In other words, it is a stance taken by people who realize the naïveté of those immersed in their activities. Cynics see the nothingness toward which everything tends (which constitutes their intellectual superiority), but keep doing it (what else to do?).

James was supposed to become, with most probability, one of those who were stolid and oblivious to the world. "No way," he said aloud. Reluctant to engage himself with the problems with (his) false consciousness, he rather turned his mind to the following situation that happened at $L N$ :

A meeting. The colleagues say that Tobiás is in Odessa, southern Ukraine, on holiday with his family. Richard comments: "If anything happens, we have a war correspondent! But don't wish it on them." We all laugh. (Field notes)

Richard had a kynical moment. His satirical remark was pointing to the uncertainty and chaos of the Russian-Ukrainian conflict and primarily to how opportunistic the media in general can be. His bitterly joking tone signified a form of subtle critique of - euphemized aggression towardboth aspects of reality. At the same time, however, it was clear-Richard knew and all the others knew as well-that if another focal point of the conflict had burst out in Odessa, the media organization would have enjoyed the unprecedented immediacy of Tobiáš's reporting, the moment of earning a reputation for being the first, and, primarily, increased readership, despite the fact that Tobiás himself would have suddenly found himself in danger (not to mention spoiled holidays). Thus, Richard also 
recognized $L N$ 's interests. Similarly to the situation with missing Vítek, Richard and all his colleagues would have been ready to get involved in building the organization's reputation and increasing its readership.

James realized the everyday-ness of this enactment of the gap between front and back stages (Goffman 1956). In the back region, the journalists were rather kynics or the ancient philosophical Cynics:

regardless of their apparent 'cynical' stance towards practically everything, [they] remained honest and truthful: they practiced, as perhaps no other human beings have, the art of truth-telling. (Navia 1996: 6)

Even James' colleagues' subtle, jokingly uttered critique of the newsmaking machine was a manifestation of the decision to use language in a truthful way.

In the front region, however, James' colleagues were often modern cynics: they maintained the consciously inauthentic mask, sticking to and reproducing the cynicism as an ideology (Sloterdijk 1987). They had got used to this specific emotional style and had learned to deploy the "defence mechanisms" (Matouš). These formed part of the journalistic emotional management techniques that the journalists were supposed to perform in order to be successful in doing their job (Illouz 2007). They merged with their emotional field.

In other words, being a comfortable (Sloterdijk 1987), cool (Peters 2011), and romanticized (Pedelty 1995) professional identity, such ideological cynicism was a result of the journalists' reflexive construction of self-identity (Giddens 1991) comprising their self-mythicization. In turn, the myth of a somewhat cynical, cool renegade was vital for the journalistic professional ideology:

It is, in short, a 'myth' - but in a particular sense of that word. Far from being a mere lie or illusion, it is a deeply held system of consciousness that profoundly affects both the structure of the news organization and the dayto-day practice of journalism. (Hallin 1986: 23)

At the same time, however, Farrukh pointed out that it is precisely this myth what forms the core of the unethical, exploitative journalism that Western journalists often perform in Global South.

James realized that the relationship between the forms of cynicism, with their diverging ways of handling the truth, and the journalistic 
professional ideology was very complex. The traditional journalistic professional ideology seemed to him at least self-contradictory (see the section "Professional Ideology and Cynicisms").

Obviously, being a good journalist - a truthful and ethical onerequires a carefully balanced combination of staying detached and being immersed; letting the emotions in and sticking to the facts. A similar skill to keep the "right distance" is an expected feature of caregivers, doctors, and employees of funeral parlors (Bernard 2008; Castra 2004; Molinier 2009). Many of the reporters-Sven, Jacob, Nicolas, Sam, Čestmír, Kryštof, and so on-compared their position to that of medical workers, in the sense that they cannot let themselves be moved too much (see Peters 2011):

I mean I have to just be a professional. Like a doctor, who has to be professional on the spot, otherwise he is not useful. You have to do what you have to do. (Sam)

The cynical emotional style, preserving the right distance, is thus a result of emotional labor (Hochschild 1983), or psychological "care of oneself," that was also crucially important for the classical Cynics (Foucault 2005).

\section{Stoics}

But taking care of one's body and soul was also essential for the Stoics: those of James' colleagues who had mastered emotional management to the extent that their emotional style was at first sight equable and peaceful and allegedly did not interfere with their personal life. Stoics were to be found mainly among the most experienced reporters; historically, they were the Cynics' philosophical successors (Sellars 2006). For the Stoics, emotions are judgments, things that are up to them, things that we can and should control. A typical Stoic, perfectly rational and indifferent to the influence of circumstances, was Jesse:

I don't get stressed out often. And I find it easy in difficult situations to keep my cool. And these are skills that I have learned and that I have sharpened over the years, which are very handy now in my work. ... I just know that in stressful situations I always stay very cool and I am quite rational and I rationalize. ... I think I am quite rational, although other people say that I am quite rational as well, so that you rationalize the options, you know what you see. (Jesse) 
Among James' colleagues, there were several Stoics who were either stoic by default or had learned to carefully measure their emotional engagement in crisis situations, or even got to stoicism via a breakdown. For example, Lotte, Marie, Carl, Čestmír, Josef, Tomáš, Sam, Sven, Tobiáš, Emil, Šimon, Nicolas, Judith, Anthony, Bob, Giuseppe, Tim, and Astrid, although certainly not emotionless, were able to take a good care of themselves and rationally assess their psychological risks. Such as Čestmír, speaking about his abduction:

These are not emotions that would — at least for me-come back in a noticeable way or that would repeat themselves, or be deposited somewhere. I mean, of course I do have it somewhere in my head. You can never delete these pictures. And ... It's not that I have PTSD. Because I also think that it's true that we don't spend as much time there as, for example, soldiers do. (Čestmír)

That Čestmír rationally assessed a traumatic experience and put it away is related to the stoic principle of "following the facts" (Becker 1998). The fact was that he was lucky and survived. Likewise, Bob, Farrukh, Nicolas, Gloria, and Anthony grounded their equilibrium in knowing that they chose to be in the crisis and/or that people that they met there were in much bigger trouble.

Rationality was essential, as both Jesse's and Čestmír's quotations suggest. Indeed, similarly to the ancient Stoics, the stoic reporters' actions and consciousness were driven not only by the effort to avoid physical death/pain but also by the need to keep their rationality and dignity:

I wanted to go to Libya now, because Libya has a new frontline, but ... it's Ramadan, first, and you cannot find anyone, they are fighting, blowing themselves up, or they are sleeping. So ... You can't do anything with that (laughs). After that, you have these sports events here, and to my feeling there is no interest when everybody is watching football or cycling or the Olympics. So I mean, what's the use of going to Libya in 50 degrees when it's too hot anyways? So I'll try to go there in the second part of August. It's still hot, but at least I would have the attention. So that's ... No, I mean I have to think economically. Also. My company. I have to do it at the right time. (Sam)

In a Stoic's words, "If I am to survive as a rational being and not merely as an animal then I must pursue those things that will help to preserve my 
rationality as well as those things that will preserve my body" (Sellars 2006: 108). Taking care of one's soul and body thus did not mean surviving at any cost but included living by a consistent set of principles. Only the possession of virtue, according to the Stoics, can bring us happiness (Sellars 2006). Correspondingly, only performing ethical journalism could satisfy the stoic reporters.

The panini did not bring James any happiness; in fact, he felt rather ill. He took the last sip from the can of beer.

\section{Coping STRategies}

Obviously, the development of various emotional styles and mind-sets, and also the potential problems mentioned above-anxiety, panic attacks, post-traumatic stress disorder, insomnia, alcoholism, and other types of mental ill-health (Dubberley et al. 2015; Feinstein et al. 2015; Hight and Smyth 2003; Høiby and Ottosen 2015; Reinardy 2011; Richards and Rees 2011; Sambrook 2016) -is a work-related phenomenon, articulated by the crisis context and by the news-production machine (see the chapter “Articulating Journalists' Emotional Experiences of Crisis: Touching Down").

James' colleagues had developed various strategies for coping with the strain: cutting oneself off from the newsfeed during days off (Marie), falling asleep in dangerous moments (Sam), long-distance running (Finn), and the above-discussed cynicism and kynicism/black humor (Matouš, Lilah). The most frequently mentioned way of dealing with traumatic experiences and other sources of work-related pressure was simply talking it through. There were two ways of talking through trauma.

Needless to say that James preferred talking with his male colleagues: he felt calmer and safe in the company of those fatherly or brotherly old hands. His male colleagues were used to debriefing with friends/colleagues over a glass of whiskey or beer (Jesse, Bob, Anthony, Nicolas, Josef, Sam, Vítek). A method tested and approved, for example, by Josef:

Luckily, I went through a course on how to fight post-traumatic syndrome, and how to avoid it. Do you know what the most important thing is? Toimmediately, ex-post, once again-go through [the traumatizing experience] in your head and tell it to someone, most preferably with alcohol. (Josef)

Talking about it with colleagues with whiskey is a kind of therapy. (Bob) 
You have to discuss with [your photographer], you have to take a beer, have a cigarette, and ... 'How do you do, are you happy with what you did today, what do you want to say?' (Nicolas, explaining how he takes care of his colleagues' mental health and averts their trauma)

For its qualities, some considered undergoing alcohol cures/rituals a specific feature of foreign affairs reporters' or international correspondents' emotional culture (see also Pedelty 1995); see also the section "Brokens":

I think there are lots of similarities [among foreign affairs reporters] and I also noticed that other people in the field sometimes smoke a lot or drink a lot. (Jesse)

This is also one of the reasons why alcohol is a bit like a crutch for the foreign correspondents. One must be careful, but it really, really helps. Of course, no one will tell you, because no one can tell you, to get drunk, it's impossible, but it was conveyed to me between the lines as an expert counsel. (Josef)

As already mentioned in the section "Brokens," some reporters were not careful and couldn't restrain themselves from drinking too much, which than had serious consequences for their personal lives.

A piece of good advice could help a lot, though. James found it nice that two of his experienced colleagues, Nicolas and Jesse, fulfilled for their younger colleagues, within their newsrooms and particularly within their parachute teams, the role of informal psychological mentors:

You have to discuss after that, in the meantime, at the end of the day. ... It's a very important thing, to discuss that, because the economic pressure on a journalist is so strong that no boss pays attention to the trauma of the journalists. (Nicolas)

The other type of talking seemed to be reserved to women. Gloria, Lilah, and Ines claimed that when they are haunted by graphic traumatic memories, they talk them through mostly with other women, typically female colleagues. Not even knowing that men have their own self-help groups, they thought that the habit of talking about trauma is a women's specialty and even advantage: 
My female colleagues, when we go through a crisis, after that we talk a lot about emotions. And my male colleagues, never. I sometimes ask them. (Laughs.) Didn't this have an impact on you? But they don't speak about that. And it seems that they don't feel anything, but I am not sure about that. (Ines)

For a woman it's very easy [to cope with traumatizing experiences]. (Laughs.) It's much easier than for a man. ... They must be the machos and stay professional. For women, it doesn't matter. ... I am not ashamed of crying, embracing somebody. (Gloria)

Gloria also protected herself against trauma by openly empathizing with the victims already in the field (and by calling them after returning to Barcelona); the feeling that she had helped someone made her feel good (see the section "Moral Dilemmas and Guilt").

James gave a sigh. It was increasingly difficult to be a man, and it must have been constantly difficult to be a woman. Luckily, both the genders had their work.

Both Nicolas and Jesse, and also Čestmír, saw their professional taskswriting and speaking - as a cathartic strategy in itself, allowing them let loose their emotions while working:

I have to write what I saw during the day. ... So it is, in some way, a kind of therapy ... then I say to my students, do not be afraid of weeping on the keyboard. (Nicolas)

As I work for radio, when a thing happens, usually within hours I must frame it and I must start talking about it. And I have noticed that for me that is the way to cope with trauma. And with graphic things. ... The sound engineers, 'cause they, they're in the same trauma, they see the same things, but they can't talk about it. (Jesse)

In its essence, the final product works as a catharsis. (Čestmír)

In this sense, the crisis reporting worked like pharmakon (Stiegler 2015), "poisoning" the reporters and providing a remedy at the same time. To compare, Hopper and Huxford (2015) speak about a "cognitive loop": doing the job of a newspaper journalist helps suppress unpleasant and paralyzing emotions stemming from doing the job, 
while suppressing emotions helps to do the job (which, as such, triggers strong emotions). Quite a few (at least ten) of James' colleagues had published at least one nonfiction book that was meant to give a more complex picture, fuller stories of people-victims, witnessesthey met in crises and better account for their own position in the field. Diego and Vítek were just promoting their freshly released oeuvres; Sven's book was adapted as a stage play and was just being rehearsed. Bob was then gathering material for his new book, Ernest was planning his travels for a book-long report (a genre that was, after a decadeslong break, on the upswing). Farrukh continued to write a brilliant blog about the distorted depiction of crisis zones in mainstream media, the ideology, and the myths behind it. To compare, Judith was just writing a manual of storytelling, advising (future) journalists how to travel down the rabbit hole. For Nicolas, the relief coming from professional, factual writing was not enough, so he started to write fiction and regularly published fictional books based on his real journalistic experience. This allowed him to express much more and subtler meanings than newspaper articles.

Taken together, the coping strategies were rather informal, individual, not institutionalized (see also Buchanan and Keats 2011 and Høiby and Ottosen 2015):

The worst thing is that one must deal with it on his own. (Josef)

One just lives the emotion through alone. ... It's a very intimate thing. (Marie)

Indeed, during his short career, James had not yet encountered any media organization that would tackle the issue systematically. Organizational documents related to breaking news and crisis reporting that James saw or heard about did not go beyond to-do lists and practical guidelines, only listing steps aiming at the highest possible organizational efficiency (see the section "'You Can't Leave Your Journalists Alone with Their Feelings': Organizational Identities").

Some media organizations (e.g. VRT or DR) did institutionalize a kind of support, which, however, came always ex-post facto. After coming from a conflict zone or a natural disaster, any journalist could call an external trauma specialist-without telling the boss-and arrange one or more 
debriefing sessions. The confidentiality was important, since potential psychological problems were considered intimate and gender-sensitive:

[Y]ou know, especially maybe for men, or for some men, it's difficult after such a severe assignment to go and say, hey, I would like to talk to someone, because I am sleeping badly. (Lotte)

According to some, such a follow-up measure was all right ("We are really investing in that, because you see unimaginable things sometimes, when you are in the field"-Lotte), although the support could be better (Jesse). By contrast, Bob was not so impressed by that: psychologists cannot do so much. "Psychologists do not have an attitude to that; I do have an attitude." This is also why the best thing one can do is talking about her trauma with fellow reporters.

At least it's something, James thought. He was wondering whether The $M o$ or Fred himself would offer him a session with a therapist after his return from San Lorenzo. James thought Fred should. If James returns.

For crisis reporting is not (only and always) an individual pursuit of masochistic pleasure. It is a politically important business. Independent and quality media are vital for democratic processes: contemporary democratic societies, constantly reflexively constructed and reconstructed (Giddens 1991), are not conceivable without established information flows, including first-hand and mediated experience with risk and crisis zones. As Wahl-Jorgensen et al. write, "Journalism plays a key role in democracies around the world, acting as a watchdog on the state and informing citizens about the decisions that affect their everyday life" (Wahl-Jorgensen et al. 2016: 810-811). Simon Cottle observes that visualized narratives, emotive testimonies, and experiential accounts can play a significant contribution in the public enactment of communicative democracy (Cottle 2009; see also Boltanski 1999). In particular,

the media's performative use of resonate symbols, dramatic visualization, narrative and embedding of emotions into ritual forms sometimes confront the strategic power of institutions and vested interests and can even lend moral gravitas to the projects of challenger groups within society. (Cottle 2009: 353)

On top of that, in crisis moments, journalists and quality media can fulfill other than purely informational roles in the affected community 
(e.g. Schudson 2011; Tong 2015). For example, given their embeddedness in decision-making processes (Hoskins and O'Loughlin 2010), media have a peacekeeping potential (Neumann and Fahmy 2016). Not to mention that the common mediated perception of global risks and crises underpin and mobilize an emergent global public sphere and global citizenship (Beck 2005).

The emotional risks of journalism in general and crisis reporting in particular not only follow from the practices that fulfill the democratizing role of media but also include the large number of new threats that limit journalists' ability to fulfill the watchdog role (Wahl-Jorgensen et al. 2016). At the same time, the multiple crisis environment, the institution of the media and its general logic, and the newsmaking processes and technologies (see the chapter "Articulating Journalists' Emotional Experiences of Crisis: Touching Down") have share in shaping the emotional styles, risks, and problems. Therefore, the risks and negative outcomes of crisis reporting should not be individualized but subjected to public, institutional, organizational, and professional prevention and resolution.

James himself came to the conclusion that we all should be more open about the journalists' authentic emotional experience. Secretly treating individual trauma and sweeping it under the carpet meant preserving the contrast between the privileged European bubble and the starving and dying Others: on one side, there is a cool, acceptably concerned yet still quite relaxed talking head from Europe, and on the other side there are thousands of dead, injured, and displaced civilians in Aleppo or the Rakhine state. The reporter narrates their story; for a while, the viewers/readers are horrified by the affairs in this or that geographically distant country. But they are not aware that the reporter cannot get rid of the smell of blood and decay (Lilah, Mario, Anthony, Ines, Jesse) and that in the next days, weeks, and months she will sleep poorly. Showing what the tragedies of the Others meant for a privileged visitor could help to build a bridge between the two worlds (see Usher 2019).

All things considered, the existing ex-post responses were not adequate to treat frequent and intense exposure to traumatizing circumstances, constant awareness of existential problems, and work-related pressure. Moreover, there was vicarious trauma (Dubberley et al. 2015), evident amongst staff working in newsrooms on the digital frontline. Exposure to graphic images and psychosocial risks were no longer limited to being on 
the spot, so that the common notion of subsequent debriefings as "therapy" was only partly grounded in reality.

Introducing prevention measures within media organizations-preparing the reporters materially and psychologically-could be more appropriate:

the best thing would be to prepare the people before you send them. ... you cannot send people to the war naked. (Gloria)

I think you should not do these things unless you are well prepared to what you might experience. You have time to get in and out of the situation, you have enough time to interview the people, to interview them in a dignifying way, and you have time to write it. (Judith)

Lilah said that even having enough time to think what she might expect helps her.

Providing psychological training and education related to possible threats, together with normalizing one's response to psychological trauma (Buchanan and Keats 2011) could reduce the discrepancy between the emerging evidence on journalists' emotional risks, the developing policies, and poor organizational practice. Implementing emotion instruction to journalism courses and textbooks could be a starting place (Hopper and Huxford 2017).

There are also sufficient legal arguments-implementations of EU directives, country-specific acts and labor codes, and Customary International Humanitarian Law (CIHL) - for why media organizations should prevent related (mental) health problems caused by work-related risks. According to the CIHL, reporters covering crisis events such as wars and conflict zones have a similar status as medical workers, members of peacekeeping missions, and humanitarian relief personnel. As such, they should be a specifically protected group. "Civilian journalists engaged in professional missions in areas of armed conflict must be respected and protected as long as they are not taking a direct part in hostilities" (Rule 34; Henckaerts and Doswald-Beck 2005: 115). The UN General Assembly and the UN Commission on Human Rights have also deplored various threats to journalists' health and safety such as harassment, intimidation, attacks, acts of reprisal, abductions, police violence, unjustified imprisonment, threats of legal prosecutions and subjection to defamation 
campaigns, threats to treat the media as enemies serving foreign powers, and denial of full and unhindered access (Henckaerts and Doswald-Beck 2005: 117-118). Some measures directed to fulfilling the CIHL have already been advanced by the Dart Centre and UNESCO's handbook for journalists reporting on terrorism (Dubberley et al. 2015; Marthoz 2017).

\section{An Overview}

Drawing energy from the trace of anger raised by the literal injustice of the almost non-existent preparations of journalists suffering from workplace dangers, James now clearly saw all the ambiguities of the journalistic emotional journey through the Russian Mountains. Newsroom routine sometimes bored the journalists to tears. Crises had the potential to interrupt the newsroom/on-the-spot boredom and could result in closeness, identification, empathy - in particular when children and parenting were at play - and strong emotional involvement. The possibility to stay emotionally detached further diminished due to the moral quandaries that the reporters often faced, the danger they experienced, and the diffused wars they involuntarily waged. At the same time, the corresponding emotional distress - the moral dilemmas, feelings of guilt, fear, and sense of responsibility-reflected themselves in the media content. However, as the next chapter will illustrate, the reporters' emotions were supposed to reflect themselves in the media content neither too strongly nor too weakly.

Reporters reacted to the emotionally demanding nature of crisis reporting by developing diverse emotional styles: mainly cynical, stoic, and, rarely, broken. The convenient, cool, and romanticized professional identity of Cynics, encompassing modern ideological cynicism and classical kynicism, was a result of the journalists' reflexive construction of selfidentity and their self-mythicization. In turn, the myth or image of a somewhat cynical, cool renegade was vital for the journalistic professional ideology (however, the complex relationship between cynical and journalistic ideology is to be further investigated). By comparison, Stoics were respecters of all kinds of rationality and of living according to a consistent set of principles.

Staying sane required the reporters to develop individual and informal coping strategies ranging from drinking-talking sessions to writing fiction and running marathons. Even though there were legal measures meant to deal with the health, safety, and stress of workers, James had not encountered any specific solutions for possible emotional distress or 
mental ill-health at the state, professional, or organizational level. The social and systemic problems were individualized and biographized (Beck and Beck-Gernsheim 2001) and the journalists carried their solutions on their shoulders (see Scheper-Hughes and Lock 1987). Media organizations did not respond appropriately to the frequent and intense exposure to traumatic circumstances, the constant awareness of existential problems, and the work-related pressure. Their negligence made the reporters' work increasingly precarious, all the more so when they worked as freelancers.

While turning left, the airplane banked. The overhead bin above James opened, and a steel case partly slid out of it, almost falling down before the robotic steward rushed to it and snapped the bin shut. It made James aware of all the technology he was dependent on.

He had no idea what was inside the case and wanted to find out.

\section{REFERENCES}

Andén-Papadopoulos, K., \& Pantti, M. (2013). Re-imagining Crisis Reporting: Professional Ideology of Journalists and Citizen Eyewitness Images. Journalism, 14(7), 960-977.

Backholm, K. (2017). Distress Among Journalists Working the Incidents. In L. C. Wilson (Ed.), The Wiley Handbook of the Psychology of Mass Shootings (Wiley Clinical Psychology Handbooks) (pp. 247-263). Chichester: John Wiley \& Sons.

Beck, U. (2005). Power in the Global Age. Cambridge: Polity.

Beck, U., \& Beck-Gernsheim, E. (2001). Individualization: Institutionalized Individualism and Its Social and Political Consequences. London: SAGE.

Becker, L. A. (1998). A New Stoicism. Princeton: Princeton University Press.

Bernard, J. (2008). Bonne distance et empathie dans le travail émotionnel des pompes funèbres: L'analyse des interactions en milieu professionnel. Journal des Anthropologues, 114-115, 109-128.

Bewes, T. (1997). Cynicism and Postmodernity. London: Verso.

Boltanski, L. (1999). Distant Suffering: Morality, Media and Politics. Cambridge: Cambridge University Press.

Buchanan, M., \& Keats, P. (2011). Coping with Traumatic Stress in Journalism: A Critical Ethnographic Study. International Journal of Psychology, 46(2), 127-135.

Carpentier, N., \& Trioen, M. (2010). The Particularity of Objectivity: A Poststructuralist and Psychoanalytical Reading of the Gap Between Objectivity-asa-value and Objectivity-as-a- practice in the 2003 Iraqi War Coverage. Journalism, 11(3), 311-328.

Castra, M. (2004). Faire face à la mort: Réguler la "bonne distance" soignantsmalades en unité de soins palliatifs. Travail et Emploi, 97, 53-64. 
Cottle, S. (2009). Global Crisis Reporting: Journalism in the Global Age. Maidenhead: Open University Press.

Creech, B. (2018). Bearing the Cost to Witness: The Political Economy of Risk in Contemporary Conflict and War Reporting. Media, Culture \& Society, $40(4), 567-583$.

Czarniawska, B. (2011). Cyberfactories: How News Agencies Produce News. Northampton: Edward Elgar.

Deuze, M., \& Witschge, T. (2018). Beyond Journalism: Theorizing the Transformation of Journalism. Journalism, 19(2), 165-181.

Dubberley, S. et al. (2015). Making Secondary Trauma a Primary Issue: A Study of Eyewitness Media and Vicarious Trauma on the Digital Frontline. Eyewitness Media Hub. Retrieved from http://eyewitnessmediahub.com/research/vicarious-trauma.

Elias, N. (1956). Problems of Involvement and Detachment. The British Journal of Sociology, 7(3), 226-252.

Falkheimer, J., \& Olsson, E. K. (2015). Depoliticizing Terror: The News Framing of the Terrorist Attacks in Norway, 22 July 2011. Media, War and Conflict, $8(1), 70-85$.

Feinstein, A., et al. (2015). Witnessing Images of Extreme Violence: A Psychological Study of Journalists in the Newsroom. Journal of the Royal Society of Medicine, 6(2), 1-7.

Festinger, L. (1957). A Theory of Cognitive Dissonance. Stanford: Stanford University Press.

Flam, H., \& Kleres, J. (Eds.). (2015). Methods of Exploring Emotions. London: Routledge.

Fleming, P., \& Spicer, A. (2003). Working at a Cynical Distance: Implications for Power, Subjectivity and Resistance. Organization, 10(1), 157-179.

Foucault, M. (2005). The Hermenentics of the Subject: Lectures at the College de France, 1981-82. New York: Palgrave Macmillan.

Galtung, J., \& Ruge, M. B. (1965). The Structure of Foreign News. Journal of Peace Research, 2(1), 64-91.

Giddens, A. (1991). Modernity and Self-Identity: Self and Society in the Late Modern Age. Cambridge: Polity Press.

Glück, A. (2016). What Makes a Good Journalist? Journalism Studies, $17(7), 893-903$.

Goffman, E. (1956). The Presentation of Self in Everyday Life. Edinburgh: University of Edinburgh.

Hallin, D. C. (1986). The "Uncensored War": The Media and Vietnam. Berkeley: University of California Press.

Hanitzsch, T. (2019). Journalism Studies Still Needs to Fix Western Bias. Journalism, 20(1), 214-217.

Harcup, T., \& O’Neill, D. (2001). What Is News? Galtung and Ruge Revisited. Journalism Studies, 2(2), 261-280. 
Henckaerts, J. M., \& Doswald-Beck, L. (2005). Customary International Humanitarian Law. Cambridge: International Committee of the Red Cross. Retrieved from https://www.icrc.org/eng/assets/files/other/customaryinternational-humanitarian-law-i-icrc-eng.pdf.

Hesmondhalgh, D., \& Baker, S. (2011). Creative Labour: Media Work in Three Cultural Industries. London: Routledge.

Hight, J., \& Smyth, F. (2003). Tragedies and Journalists: A Guide for More Effective Coverage. Dart Center for Journalism and Trauma. Retrieved from http://dartcenter.org/sites/default/files/en_tnj_0.pdf.

Hochschild, A. R. (1983). The Managed Heart. Berkeley: University of California Press.

Høiby, M. H., \& Ottosen, R. (2015). Journalism Under Pressure: A Mapping of Editorial Policies for Journalists Covering Conflict. Oslo: Høgskolen i Oslo og Akershus.

Hopper, K. M., \& Huxford, J. (2015). Gathering Emotion: Examining Newspaper Journalists' Engagement in Emotional Labor. Journal of Media Practice, $16(1), 25-41$.

Hopper, K. M., \& Huxford, J. (2017). Emotion Instruction in Journalism Courses: An Analysis of Introductory News Writing Textbooks. Communication Education, 66(1), 90-108.

Hoskins, A., \& O'Loughlin, B. (2010). War and Media: The Emergence of Diffused War. Cambridge: Polity Press.

Illouz, E. (2007). Cold Intimacies: The Making of Emotional Capitalism. Cambridge: Polity Press.

Jukes, S. (2017). Affective journalism - Uncovering the Affective Dimension of Practice in the Coverage of Traumatic News. PhD Thesis, Goldsmiths University, United Kingdom.

Marthoz, J. P. (2017). Terrorism and the Media: A Handbook for Journalists. Paris: UNESCO.

McDonald, I. R., \& Lawrence, R. G. (2004). Filling the $24 \times 7$ News Hole: Television News Coverage Following September 11. American Behavioral Scientist, 48(3), 327-340.

Mejias, U. A., \& Vokuev, M. E. (2017). Disinformation and the Media: The Case of Russia and Ukraine. Media, Culture and Society, 39(7), 1027-1042.

Moeller, S. D. (1999). Compassion Fatigue: How the Media Sell Disease, Famine, War and Death. London: Routledge.

Molinier, P. (2009). Temps professionnel et temps personnel des travailleuses du care: Perméabilité ou clivage? Les aléas de la "bonne distance". Temporalités, 9, 1-14.

Navia, L. E. (1996). ClassicalCynicism: A CriticalStudy. London: Greenwood Press.

Neumann, R., \& Fahmy, S. (2016). Measuring Journalistic Peace/War Performance: An Exploratory Study of Crisis Reporters' Attitudes and Perceptions. International Communication Gazette, 78(3), 223-246. 
Nord, L. W., \& Strömbäck, J. (2003). Making Sense of Different Types of Crises: A Study of the Swedish Media Coverage of the Terror Attacks Against the United States and the U.S. Attacks in Afghanistan. Press/Politics, 8(4), 54-75.

Nord, L. W., \& Strömbäck, J. (2006). Reporting More, Informing Less: A Comparison of the Swedish Media Coverage of September 11 and the Wars in Afghanistan and Iraq. Journalism, 7(1), 85-110.

Örnebring, H. (2009). Comparative European Journalism: The State of Current Research. Working paper. Oxford: Reuters Institute for the Study of Journalism.

Pantti, M. (2010). The Value of Emotion: An Examination of Television Journalists' Notions on Emotionality. European Journal of Communication, 25(2), 168-181.

Pedelty, M. (1995). War Stories: The Culture of Foreign Correspondents. London: Routledge.

Peters, C. (2011). Emotion Aside or Emotional Side? Crafting an 'Experience of Involvement' in the News. Journalism, 12(3), 297-316.

Reinardy, S. (2011). Newspaper Journalism in Crisis: Burnout on the Rise, Eroding Young Journalists' Career Commitment. Journalism, 12(1), 33-50.

Richards, B., \& Rees, G. (2011). The Management of Emotion in British Journalism. Media, Culture and Society, 33(6), 851-867.

Rosaldo, M. Z. (1984). Towards an Anthropology of Self and Feeling. In R. A. Schweder \& R. A. LeVine (Eds.), Culture Theory: Essays on Mind, Self and Emotions (pp. 137-157). Cambridge: Cambridge University Press.

Rosen, J. (2011). September 11 in the Mind of American Journalism. In B. Zelizer \& S. Allan (Eds.), Journalism After September 11 (2nd ed., pp. 35-43). London: Routledge.

Rosenkranz, T. (2019). From Contract to Speculation: New Relations of Work and Production in Freelance Travel Journalism. Work, Employment and Society. Epub ahead of print 20 January 2019. https://doi.org/10.1177/ 0950017018793344.

Russia's Dark Arts: An investigative series on Russia's covert projection of power. (2016). New York Times. Retrieved from https://www.nytimes.com/series/ russias-dark-arts.

Rutten, E., et al. (Eds.). (2013). Memory, Conflict and New Media: Web Wars in Post-socialist States. London: Routledge.

Sambrook, R. (2016, April 11). Newsrooms Should Prepare to Cover Terrorist Attacks. International News Safety Institute. Retrieved from http://www. newssafety.org/news/insi-news/insi-news/detail/newsrooms-should-prepare-to-cover-terrorist-attacks-1722/.

Scheer, M. (2012). Are Emotions a Kind of Practice (And Is That What Makes Them Have a History)? A Bourdieuian Approach to Understanding Emotion. History and Theory, 51, 193-220. 
Scheper-Hughes, N., \& Lock, M. (1987). The Mindful Body: A Prolegomenon to Future Work in Medical Anthropology. Medical Anthropology Quarterly, $1(1), 6-41$.

Schudson, M. (2011). What's Unusual About Covering Politics as Usual. In B. Zelizer \& S. Allan (Eds.), Journalism after September 11 (2nd ed., pp. 44-54). London: Routledge.

Sellars, J. (2006). Stoicism. London: Routledge.

Sloterdijk, P. (1987). Critique of Cynical Reason. Minneapolis: University of Minnesota Press.

Sontag, S. (2003). Regarding the Pain of Others. New York: Picador.

Statista. (2019). Unemployment Rate in Member States of the European Union in June 2018 (seasonally adjusted). The Statistics Portal. Retrieved from https://www.statista.com/statistics/268830/unemployment-rate-in-eucountries/.

Stiegler, B. (2015). Numérique, éducation et cosmopolitisme. Cités, 63, 13-36.

The Guardian. (2003, December 5). Journalists Jailed for Inciting Rwandan Genocide. The Guardian. Retrieved from https://www.theguardian.com/ media/2003/dec/04/pressandpublishing.radio.

Tong, J. (2015). Being Objective with a Personal Perspective: How Environmental Journalists at Two Chinese Newspapers Articulate and Practice Objectivity. Science Communication, 37(6), 747-768.

Tumber, H. (2011). Reporting Under Fire: The Physical Safety and Emotional Welfare of Journalists. In B. Zelizer \& S. Allan (Eds.), Journalism After September 11 (2nd ed., pp. 319-334). London: Routledge.

Usher, N. (2019). Journalism's Biggest Challenge? Journalists. Journalism, 20(1), 140-143.

Van Zoonen, L. (1998). A Professional, Unreliable, Heroic Marionette (M/F): Structure, Agency and Subjectivity in Contemporary Journalisms. European Journal of Cultural Studies, 1(1), 123-143.

Wahl-Jorgensen, K., et al. (2016). The Future of Journalism. Digital Journalism, $4(7), 809-815$.

Waisbord, S. (2019). The Vulnerabilities of Journalism. Journalism, 20(1), 210-213.

Weick, K. E. (1995). Sensemaking in Organizations. London: SAGE.

Zelizer, B., \& Allan, S. (Eds.). (2011). Journalism After September 11 (2nd ed.). London: Routledge. 
Open Access This chapter is licensed under the terms of the Creative Commons Attribution 4.0 International License (http://creativecommons.org/licenses/ by $/ 4.0 /$ ), which permits use, sharing, adaptation, distribution and reproduction in any medium or format, as long as you give appropriate credit to the original author(s) and the source, provide a link to the Creative Commons licence and indicate if changes were made.

The images or other third party material in this chapter are included in the chapter's Creative Commons licence, unless indicated otherwise in a credit line to the material. If material is not included in the chapter's Creative Commons licence and your intended use is not permitted by statutory regulation or exceeds the permitted use, you will need to obtain permission directly from the copyright holder.

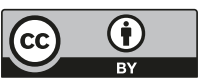

